\title{
Pengaruh Ketahanmalangan dan Regulasi Diri terhadap Kompetensi Pengetahuan Matematika
}

\author{
Ni Pt. Krisna Hari1* ${ }^{*}$ Gusti Ngurah Sastra Agustika², I Gusti Agung Ayu Wulandari 3 \\ ${ }^{123}$ Program Studi Pendidikan Guru Sekolah Dasar, Universitas Pendidikan Ganesha, Singaraja, Indonesia
}

\begin{abstract}
Abstrak
Rendahnya pengetahuan matematika siswa yang disebabkan oleh beberapa faktor yang mendominasi serta kurangnya sumber mengenai ketahanmalangan dan regulasi diri sehingga penelitian ini bertujuan untuk menganalisis pengaruh ketahanmalangan dan regulasi diri terhadap kompetensi pengetahuan matematika siswa dengan desain penelitian Korelasional. Populasi yang digunakan adalah siswa

Kata Kunci:

Ketahanmalangan, Regulasi Diri,

Kompetensi

Pengetahuan

Matematika, Siswa kelas V SD yang berjumlah 258 siswa. Sampel ditentukan dengan Teknik cluster random sampling. Pengumpulan data dilakukan dengan pengisian angket tentang ketahanmalangan dan regulasi diri, sedangkan data kompetensi pengetahuan matematika diperoleh melalui pencatatan dokumen. Analisis statistika pada penelitian ini menggunakan regresi linier sederhana dan regresi linier berganda. Hasil dari analisis regresi linier sederhana untuk pengujian hipotesis I dan II hasil yang diiperoleh dengan pengaruhnya sebesar 36\% dan $25.6 \%$. Hasil analisis regresi linier ganda ditemukan persamaan $\hat{Y}=37.41+0.175 \mathrm{X}_{1}+0.24 \mathrm{X}_{2}$ dan hasil $\mathrm{F}_{\text {reg }}=27.0>\mathrm{F}_{\text {tabel }}=$ 3,05 yang berarti signifikan dan terdapat pengaruh antara ketahanmalangan dan regulasi diri terhadap kompetensi pengetahuan Matematika siswa kelas V SD dan berpengaruh sebesar $25 \%$.
\end{abstract}

\footnotetext{
Abstract

This low knowledge mathematics students caused by several factors who dominated and the lack of adversity quotient and self-regulation on themselves so that research that aims to find the impact of adversity quotient and self-regulation on the competency of students' mathematical knowledge by correlational research design. Fifth grade students of the Elementary School population are used in this

Keywords:

Adversity Qoutient,Selfregulation, Mathematic knowledge competency, Students research the amount of it is 258 students. Cluster random sampling technique is used as the sample. The data collection is done by filling out some questionnaires about the adversity quotient and self-regulation, while the competency data of mathematical knowledge is obtained through documentation recording. Statistical analysis in this research uses simple linear regression and multiple linear regression. The results of simple linear regression analysis to test the hypothesis I and II, it is obtained with its effect of $36 \%$ and $25.6 \%$. The results of multiple linear regression analysis is found equal signs $\hat{Y}=37.41+0.175 \mathrm{X} 1+0.24 \mathrm{X} 2$ and the results of Freg $=27.0>$ Ftabel $=3,05$, which means significant and there is an adversity quotient between self-regulation on the competency of fifth grade students on mathematics knowledge and it has an effect of $25 \%$.
}

\footnotetext{
* Corresponding author. 


\section{PENDAHULUAN}

Matematika merupakan ilmu pasti yang memberikan pengaruh dan dapat meningkatkan kemampuan berpikir individu agar dapat diterapkan dalam kehidupan sehari-hari (Fadhilah, 2020). Matematika juga merupakan ilmu yang di dalamnya terdapat proses berfikir seseorang secara masuk akal sehingga mampu memperoleh konsep (Amelia, 2018). Matematika juga merupakan ilmu universal yang mendasari perkembangan teknologi modern (Ayulina \& Sastra , 2020).

Hamdi et al. (2018) mengungkapkan bahwa mata pelajaran matematika adalah salah satu bidang pengetahuan yang memiliki peran sentral dalam pengembangan kompetensi yang dibutuhkan untuk menghadapi lingkungan abad 21. Pemahaman matematika adalah pusat kesiapan generasi muda untuk hidup dalam masyarakat modern (Umam \& Hidayanto, 2018). Sehingga di dalam pembelajaran matematika tentu, diperlukan berbagai upaya dari guru serta siswa agar tercapainya tujuan dari setiap pembelajaran yang di laksanakan. Sebagai dasar ilmu berkembangnya pengetahuan dan teknologi modern, matematika serta berperan memajukan daya pikir manusia. Pada berbagai bidang, cabang ilmu ini berguna untuk menyelesaikan masalah hingga akhirnya digunakan sebagai standar yang menentukan kemajuan pendidikan di suatu negara (Retnawati \& Anazifa , 2018). Pada hakikatnya, matematika dapat memberikan tekanan penataran nalar dalam penerapannya. Keberhasilan dalam pendidikan tidak terlepas dari kurikulum yang mencakup isi maupun tujuan pendidikan yang dijadikan sebagai acuan dalam menyelenggarakan pendidikan. Dalam menciptakan suasana pembelajaran kondusif bagi siswa khususnya pada tingkat sekolah dasar yaitu melaksanakan berbagai rancangan dalam mengajar agar tujuan pembelajaran tercapai. Pencapaian tujuan pendidikan dapat dipenuhi dari pencapaian kompetensi pengetahuan pada masing-masing muatan materi salah satunya adalah kompetensi pengetahuan Matematika. Kompetensi pengetahuan dapat dengan jelas mengukur kemampuan dalam memahami dan menguasai isi dari suatu materi atau bahan pelajaran (Handayani \& Abadi, 2020) . Pengetahuan dasar matematika menjadi faktor penentu terhadap kemampuan siswa dalam mendalami materi selanjutnya (Anisa et al., 2019) . Jadi kompetensi pengetahuan matematika yaitu perpaduan antara pengetahuan dan keterampilan yang dikuasai seseorang yang dibangun untuk mengembangkan dan meningkatkan kemampuan berpikir, pola perilaku atau tindakan yang dilakukan seseorang dengan sebaik-baiknya.

Perlu disadari dalam mempelajari ilmu matematika, seseorang dituntut memiliki ketelitian agar mendapatkan hasil yang benar dan tepat. Matematika menjadi patokan kecerdasan seseorang. Banyak ditemui masalah dalam pendidikan matematika, diantaranya adalah pandangan individu yang berbeda. Ada yang merasa bahwa matematika sangat menantang dan ada yang merasa bahwa matematika sangat menyulitkan. Berdasarkan hasil wawancara dengan guru sekolah dasar, mengatakan bawa " pengetahuan matematika siswa jauh dari kategori baik dilihat dari nilai ulangan pada semester I. Dari uaraian tersebut, maka matematika merupakan pelajaran yang harusnya menyenangkan dan selalu dibuat menarik agar individu lebih menyukai matematika sehingga materinya tidak hanya sebatas teori semata saja tetapi juga dapat diterapkan sehingga dengan demikian pengetahuan siswa akan matematika akan terlihat. Kebanyakan individu menganggap bahwa untuk meraih pengetahuan, seseorang harus memiliki (IQ) yang tinggi dan juga mempunyai (EQ) karena keduanya memainkan suatu peran (Stoltz, 2007). Ketahanmalangan berakar dari bagaimana seseorang merasakan dan menghubungkan dirinya dengan tantangan-tantanggan dalam hidupnya (Hibatul, 2019). Ketahanmalangan dapat dipandang sebagai ilmu yang menganalisis kegigihan manusia dalam menghadapi sikap tantangan dalam hidupnya. Ketahanmalangan itu merupakan jiwa individu, karena dengan adanya ketahanmalangan seseorang mampu bertahan dalam menghadapi segala permasalahan dalam hidupnya dan menilai bahwa masalah merupakan suatu peluang bukan hambatan (Suhendri \& Ningsih, 2018). Ketahanmalangan adalah sikap individu yang memiliki daya juang pantang menyerah saat dihadapkan dengan berbagai masalah khususnya dalam pembelajaran, tidak mengulangi kesalahan yang diperbuat, dan selalu menerima tanggung jawab dari berbagai masalah yang datang dimana individu itu mampu mengontrol perasaan dan terampil dalam menyelesaikan masalah (Widnyana, 2017). Ketahanmalangan yang ada pada siswa menjadikan siswa tersebut kuat dalam segala rintangan yang di dapatkannya dalam proses pembelajaran. Jadi, secara umum dapat dikatakan bahwa ketahanmalangan merupakan kemampuan individu dalam menghadapi kesulitan atau kemalangan dan keadaan yang tidak diinginkan. Namun ketahanmalangan seseorang berbeda-beda dalam pembelajaran dan dapat mempengaruhi kompetensi pengetahuan individu itu sendiri. Dalam pendidikan pengetahuan siswa dipengaruhi oleh salah satu faktor yaitu ketahanmalangan, karena ketehanmalangan merupakan sikap daya juang yang dimikili seseorang. Maka, pada dasarnya ketahanmalangan merupakan kecerdasan yang ada pada setiap diri seseorang atau dalam diri siswa dalam menghadapi tantangan hambatan atau kesulitan-kesulitan dalam hidup, tetapi tergantung dari tinggi rendahnya. Dalam hal ini, jika siswa memiliki ketahanmalangan yang cukup menunjang, siswa tersebut cenderung akan mampu untuk mengatasi segala kesulitan dengan kecerdasan 
yang dimilikinya. Seseorang yang memanfaatkan ketahanmalangan secara optimal dalam hidupnya akan dapat mengatasi setiap persoalan hidupnya tanpa pantang menyerah. Dimensi pada ketahanmalangan yaitu (1) Kendali dalam ketahanmalangan yang berkaitan dengan seseorang yang dapat mengendalikan dirinya bila dihadapkan dengan tantangan ataupun kesulitan. (2) Asal Usul dan Pengakuan dikaitkan dengan darimana dan sejauh apa individu mengakui kesalahan-kesalahan atau tantangan yang ia perbuat sendiri. Individu yang menganggap kesulitan itu faktor dari luar artinya individu itu memiliki ketahanmalangan yang tinggi begitu sebaliknya. (3) Jangkauan merupakan bagian dari dimensi ketahanmalangan dimana sejauh apa individu mengganggap tantangan itu akan meluas ke hal lainnya dan menganggap tantangan itu sebagai bencana untuk kedepannya. (4) Daya tahan merupakan dimensi ketahanmalangan dimana individu dengan daya tahan yang tinggi akan mengganggap tantangan itu sifatnya sementara dan ia akan bias melewatinya, begitu sebaliknya jika individu dengan daya tahan rendah akan menggangap tantangan itu bertahan lama dan berlarut-larut.

Stoltz (2007) mengungkapkan bahwa pekerjaan dan hidup seseorang yang menjadi sukses dipengaruhi oleh ketahanmalangan. Pendapat tersebut sejalan dengan penelitian Dewi (2017) yang menyatakan bahwa ketahanmalangan merupakan penggerak tujuan hidup kedepan dan juga sebagai pengukuran tentang bagaimana seseorang merespon kesulitan. Jika dikaitkan dengan cara menghadapi kesulitan, regulasi diri lah yang dibutuhkan, karena cara individu menempatkan dirinya untuk mencapai tujuan disebut regulasi diri (Ghufron, 2017). Regulasi diri yang siswa miliki dapat membantu siswa mengontrol emosi, pikiran dan tindakan untuk mencapai tujuan. Regulasi diri merupakan faktor penting dalam belajar karena ikut menentukan keberhasilan siswa dalam mencapai prestasinya (Nur, 2016). Siswa yang mengenal dirinya sendiri dan mengetahui cara belajar yang baik dan sebenarnya disebut dapat meregulasikan dirinya sendiri (Kusaeri \& Mulhamah, 2016). Regulasi diri juga merupakan proses dimana individu belajar secara aktif sebagai pengatur proses belajarnya sendiri (Artyanti \& Rustika, 2016). Dengan regulasi diri yang individu miliki membuat individu tersebut menjadi lebih terencana dan terarah dalam melangkah untuk memulai suatu hal dan dapat dimudahkan dalam pelaksanaannya (Setiawan, 2017). Regulasi diri dilihat dari kemampuan siswa dalam mengikuti proses kegiatan belajar mengajar di sekolah yang dapat mempengaruhi pengetahuan siswa maka dari itu, regulasi diri siswa haruslah tinggi dan selalu di asah (Putry \& Putri, 2017). Proses regulasi diri juga berlangsung secara terus menerus sampai tercapainya tujuan. Kedua faktor tersebut memiliki peranan dalam pembelajaran matematika. Dari beberapa pengertian, maka regulasi diri adalah sikap seseorang yang mampu memposisikan dirinya dengan mengaitkan metakognitif, motivasi dan perilaku agar dapat mengatur diri agar dapat mencapai tujuan tertentu. Dimensi regulasi diri yaitu (1) Metakognitif adalah pemikiran seseorang mengenai hal yang diketahui maupun tidak. (2) Motivasi adalah tekad untuk melakukan sesuatu atau keingininannya melalui suatu dorongan atau perubahan yang individu itu lakukan. (3) Perilaku yaitu respon atau tindakan yang diberikan individu terhadap kehadiran stimulus. Perilaku juga menjadi upaya seseorang untuk mengendalikan lingkungan dan aktivitas yang dilakukan. Tidak semua siswa memiliki regulasi diri yang baik dalam belajar, karena regulasi diri ditandai dari ketidakmampuannya untuk mengarahkan dirinya saat belajar (Maulana, 2019). Berdasarkan paparan di atas, peneliti termotivasi untuk mengetahui seberapa besar pengaruh ketahanmalangan dan regulasi diri terhadap kompetensi pengetahuan matematika siswa kelas V SD Negeri Gugus I Gusti Ngurah Rai Kecamatan Denpasar Timur Tahun Ajaran 2019/2020.

\section{METODE PENELITIAN}

Penelitian ini memuat dua variabel bebas dan satu variabel terikat, yaitu ketahanmalangan $\left(\mathrm{X}_{1}\right)$ sebagai variabel bebas pertama, Regulasi Diri $\left(\mathrm{X}_{2}\right)$ sebagai variabel bebas ke dua dan kompetensi pengetahuan matematika (Y) sebagai variabel terikat. Desain penelitian lebih jelasnya dapat dilihat pada gambar berikut. 


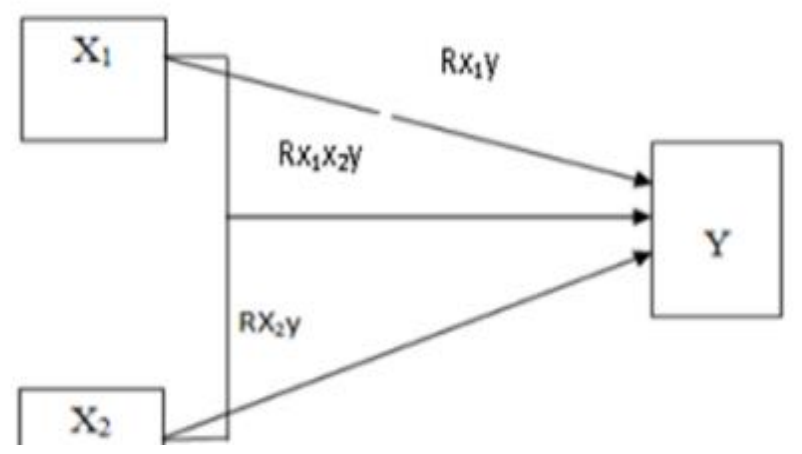

Gambar 1. Rancangan Penelitian

Populasi yang digunakan yaitu seluruh siswa kelas V yang terdiri dari 7 SD dan sampel yang diambil menggunakan teknik Cluster random sampling. (Sukardi, 2012) "cluster sampling dipilih dengan tidak secara individual, tetapi lebih secara berkelompok." Sehingga dalam penelitian ini, yang di random adalah kelompok kelas. Pemilihan cluster dilakukan secara acak dengan sistem undian yang dilakukan setelah terlebih dahulu menentukan jumlah sampel minimal yang dibutuhkan untuk mewakili populasi. Penetapan untuk jumlah sampel minimal menggunakan rumus dari slovin dan berdasarkan rata-rata jumlah siswa tiap kelas, didapatkan sebanyak enam cluster yang digunakan untuk dapat memenuhi syarat sampel minimal. Penentuan enam cluster tersebut dilakukan melalui sistem undian. Data kompetensi pengetahuan matematika diperoleh melalui pencatatan dokumen dengan melihat nilai ulangan siswa pada semester I. Instrumen yang digunakan untuk mengumpulkan data ketahanmalangan adalah kuesioner ketahanmalangan terdiri dari 24 butir pernyataan dengan indikatornya yaitu Anak mampu mengkondisikan keadaan yang menimbulkan kesulitan, anak mampu mengendalikan dirinya terhadap kesulitan, anak semangat dalam menghadapi kesulitan, anak dapat menemukan asal-usul kesulitan, anak berani mengakui dan bertanggu jawab atas masalah yang dilakukannya, anak dapat membatasi jangkauan kesulitannya, anak tetap berdaya dan tidak kewalahan, anak menunjukkan daya tahannya dan anak selalu optimis. Kuesioner atau angket yang digunakan bersifat tertutup dimana pernyataan-pernyataan dan alternatif jawabannya yang berkaitan dengan variabel yang akan diukur telah disediakan dan responden dapat memilih jawaban tersebut. Alternatif jawaban pada kueosioner ini mengacu pada skala likert dengan rentang skor $1-4$.

Data regulasi diri diukur menggunakan kuesioner regulasi diri, Kuesioner regulasi diri ini terdiri dari 25 butir pernyataan. Adapun indikator mengenai regulasi diri yaitu anak memiliki perencanaan, anak memiliki orientasi tujuan, anak mampu mengatur dirinya, anak mampu mengevaluasi dirinya, anak memiliki hasrat dan keinginan untuk berhasil, anak mampu menata kepemilikannya dan lingkungan. Kuesioner atau angket yang digunakan bersifat tertutup dimana pernyataan-pernyataan dan alternatif jawabannya yang berkaitan dengan variabel yang akan diukur telah disediakan dan responden dapat memilih jawaban tersebut. Alternatif jawaban pada kueosioner ini mengacu pada skala likert dengan rentang skor 1-4. Item pernyataan tersebut sudah diuji kelayakannya dengan uji validitas dan reliabilitas. 24 item pernyataan ketahanmalangan termasuk pada kategori sangat tinggi dengan $r_{11}=1,04$, sedangkan 25 item pernyataan regulasi diri termasuk pada kategori sangat tinggi dengan $r_{11}=0,81$. Kategori ini diperoleh dari hasil hitung reliabilitas yang dibandingkan dengan derajat reliabilitas. Selanjutnya, metode analisis data yang digunakan yaitu statistik inferensial. Uji prasyarat analisis regresi yang dilakukan sebelum ke tahap uji hipotesis data yaitu uji normalitas, uji linieritas, uji multikolinieritas dan uji heteroskesdastisitas. Setelah uji prasyarat terpenuhi, berikutnya dilakukan uji hipotesis menggunakan regresi linier sederhana untuk uji hipotesis I dan II dan regresi linier berganda untuk uji hipotesis III.

\section{ANALISIS DAN PEMBAHASAN}

Secara teoritis ketahanmalangan dan juga regulasi diri memiliki peran untuk memacu setiap individu dan setiap siswa khususnya agar bisa mendapatkan pengetahuan yang baik dan berpengaruh positif terhadap pengetahuan siswa khususnya pengetahuan matematika. Sebelum melalukan pengujian hipotesis, dapat dilakukan pendeskripsian data dan uji asumsi klasik terlebih dahulu yang meliputi uji normalitas, uji linieritas, uji multikolinieritas dan uji heterokesdastisitas. Data yang dipaparkan dalam 
penelitian ini adalah data ketahanmalangan dan regulasi diri sebagai variabel bebas (X) dan data kompetensi pengetahuan matematika sebagai variabel terikat (Y). Data kompetensi pengetahuan matematika yang dijadikan sampel penelitian sebanyak 160 siswa dan diberikan kuesioner sebanyak 25 butir pernyataan. Deskripsi data sampel penelitian disajikan dalam tabel deskripsi data. Mengnai data kompetensi pengetahuan matematika dapat dilihat pada tabel sebagai berikut.

Tabel 1. Deskripsi Data Kompetensi Pengetahuan Matematika

\begin{tabular}{lc}
\hline \multicolumn{1}{c}{ Analisis Statistik } & Kompetensi Pengetahuan Matematika \\
\hline Jumlah Sampel & 160 \\
Skor Maksimum & 88 \\
Skor Minimum & 53 \\
Mean & 71 \\
Median & 71 \\
Modus & 70 \\
Standar Deviasi & 6,06 \\
Varians & 36,77 \\
\hline
\end{tabular}

Berdasarkan Tabel 1. kompetensi pengetahuan matematika siswa kelas V pada sekolah sampel termasuk baik karena dilihat dari rata-rata kompetensi pengetahuan Matematik siswa adalah 88 dan konversi PAP pada rentang 80-89 yang dinyatakan berkategori baik. Mengenai data ketahanmalangan dapat dilihat juga melalui Tabel sebagai berikut.

Tabel 2. Deskripsi Data Ketahanmalangan

\begin{tabular}{|c|c|}
\hline Analisis Statistik & Ketahanmalangan \\
\hline Sampel & 160 \\
\hline Skor Maksimum & 88 \\
\hline Skor Minimum & 66 \\
\hline Mean & 79,48 \\
\hline Median & 79 \\
\hline Modus & 79 \\
\hline Standar Deviasi & 6,5 \\
\hline Varians & 42,5 \\
\hline
\end{tabular}

Berdasarkan Tabel 2. bahwa rata-rata (mean) dari ketahanmalangan siswa adalah 79,48 dan rata-rata tersebut terdapat pada rentang $78-96$, pada kategori skor sangat baik dalam skala interval lima teoritik. Mengenai data regulasi diri dapat juga dilihat melalui tabel sebagai berikut.

Tabel 3. Deskripsi Data Regulasi Diri

\begin{tabular}{lc}
\hline \multicolumn{1}{c}{ Analisis Statistik } & Regulasi Diri \\
\hline Sampel & 160 \\
Skor Maksimum & 96 \\
Skor Minimum & 57 \\
Mean & 86,4 \\
Median & 80 \\
Modus & 79 \\
Standar Deviasi & 8,94 \\
Varians & 80,0 \\
\hline
\end{tabular}

Berdasarkan Tabel 3. bahwa rata-rata (mean) dari regulasi diri siswa adalah 86,4 dan rata-rata tersebut terdapat pada rentang 81,25 - 100 kategori skor sangat baik dalam skala interval lima teoritik. Uji normalitas, uji llinieritas, uji multikolinieritas, dan uji heterokesdastisitas dilakukan sebelum ketahap uji hipotesis. Uji normalitas digunakan untuk melihat residual sebaran data yang dimiliki berasal dari sebaran normal atau tidak. Uji normalitas yang digunakan adalah menggunakan teknik Kolmogorov Smirnov dengan menguji nilai residual tiap variabel yaitu residual dari $\mathrm{X}_{1}$ terhadap $\mathrm{Y}, \mathrm{X}_{2}$ terhadap $\mathrm{Y}$ serta $\mathrm{X}_{1}$ dan $\mathrm{X}_{2}$ terhadap $\mathrm{Y}$. Uji normalitas nilai residu dianalisis dengan berbantuan aplikasi Microsoft Excel 
2010. Perolehan dari hasil perhitungan, nilai $\left|F_{T}-F_{S}\right|$ maksimal adalah 0,057. Selanjutnya yaitu membandingkan hasil $\left|\mathrm{F}_{\mathrm{T}}-\mathrm{F}_{\mathrm{S}}\right|$ maksimal dengan nilai tabel Kolmogorov Smirnov. Berdasarkan tabel Kolmogorov Smirnov diperoleh nilai 0,107, dengan demikian 0,057< 0,107 maka $\mathrm{H}_{0}$ diterima, sehingga dapat disimpulkan bahwa nilai residual ketahanmalangan terhadap kompetensi pengetahuan matematika berdistribusi normal. Langkah- langkah ini juga digunakan untuk mencari data residual regulasi diri terhadap kompetensi pengetahuan matematika, serta ketahanmalangan, dan regulasi dri terhadap kompetensi pengetahuan matematika dan dapat dilihat melalui tabel sebagai berikut.

Tabel 4. Hasil Uji Normalitas Nilai Residual Siswa

\begin{tabular}{lccc}
\hline \multicolumn{1}{c}{ Variabel } & $\mid \mathbf{F t}-\mathbf{F} \mathbf{\text { Max }}$ & Ks Tabel & Kesimpulan \\
\hline $\begin{array}{l}\text { Ketahanmalangan dengan kompetensi } \\
\text { pengetahuan matematika (X1Y) }\end{array}$ & 0,057 & 0,107 & Data Berdistribusi Normal \\
$\begin{array}{l}\text { Regulasi diri dengan kompetensi } \\
\text { pengetahuan matematika (X2Y) }\end{array}$ & 0,059 & 0,107 & Data Berdistribusi Normal
\end{tabular}

Ketahanmalangan dan regulasi diri

dengan

kompetensi pengetahuan matematika

Data Berdistribusi Normal (X1X2Y)

Berdasarkan Tabel 4. Dapat dilihat bahwa data ketahanmalangan terhadap kompetensi pengetahuan matematika, regulasi diri terhadap kompetensi pengetahuan matematika, ketahanmalangan dan regulasi terhadap kompetensi pengetahuan matematika berdistribusi normal dengan nilai |Ft-Fs| Max berturut-turut 0,057, 0,059, dan 0,063.

Uji linearitas dilakukan untuk mengetahui hubungan antara ketahamalangan dengan kompetensi pengetahuan matematika dan hubungan antara regulasi diri dengan kompetensi pengetahuan matematika. Kriteria pengujian linearitas Deviation for Linierity yaitu, jika $\mathrm{f}_{\text {hitung }}$ lebih besar dari Taraf Signifikan maka dapat ditarik kesimpulan bahwa antara variabel X dan Y memiliki hubungan yang liniear. Pengujian linearitas dilakukan dengan bantuan aplikasi program SPSS Versi 21.0 dan dari dari hasil yang didapatkan harga $F_{\text {hitung }}=0,485>0,05$ dapat disimpulkan bahwa data $\mathrm{X}_{1}$ terhadap $\mathrm{Y}$ atau data ketahanmalangan terhadap kompetensi pengetahuan matematika bersifat linear. Uji linear data $\mathrm{X}_{2}$ terhadap Y atau data ketahanmalangan terhadap kompetensi pengetahuan matematika juga bersifat linear, dimana harga harga $F_{\text {hitung }}=0,932>0,05$. Hasil uji linieritas juga dapat dilihat dari output program SPSS dalam bentuk tabel sebagai berikut.

Tabel. 5. Hasil Uji Linieritas Data Siswa

\begin{tabular}{|c|c|c|c|}
\hline Variabel & $\begin{array}{c}\text { Deviation from } \\
\text { Linearity }\end{array}$ & Taraf Signifikan & Kesimpulan \\
\hline $\begin{array}{l}\text { Ketahanmalangan dengan } \\
\text { kompetensi } \\
\text { pengetahuan Matematika (X1Y) }\end{array}$ & 0,485 & 0,05 & Linier \\
\hline $\begin{array}{l}\text { Regulasi Diri r dengan } \\
\text { kompetensi } \\
\text { Matematika (X2Y) }\end{array}$ & 0,932 & 0,05 & Linier \\
\hline
\end{tabular}

Berdasarkan Tabel 5. Dapat dilihat bahwa data ketahanmalangan terhadap kompetensi pengetahuan matematika, regulasi diri terhadap kompetensi pengetahuan matematika bersifat linier, dengan nilai Deviation From Linierity berturut-turut 0,485 dan 0,932. Uji Multikolinieritas dilakukan untuk mengetahui hubungan linear antar variabel independen dalam sebuah model regresi. Uji multikolinieritas menggunakan aplikasi program SPSS Versi 21.0 yaitu melihat nilai Variance Inflation Factor (VIF) dan Collinierity Tolerance. Metode regresi dianggap baik jika nilai Variance Inflation Factor (VIF) dibawah $10(\leq 10)$ dan nilai Collinierity Tolerance diatas 0,1 $(\geq 0,1)$. Hasil analisis yang didapat dan dapat, VIF 1,009 dan TOL sebesar 0,991 maka disimpulkan bahwa tidak terjadi multikolinieritas dikarenakan Tol > 0,1 dan VIF < 10. Hasil uji multikolinieritas juga dapat dilihat dari output program SPSS dalam bentuk tabel sebagai berikut. 
Tabel 6. Hasil Uji Multikolinieritas Data Siswa

\begin{tabular}{lccc}
\hline \multicolumn{1}{c}{ Variabel } & Tolerance & VIF & Ket \\
\hline Ketahanmalangan & 0,991 & 1,009 & Tidak Terjadi Multikolinieritas \\
Regulasi Diri & 0,991 & 1,009 & Tidak Terjadi Multikolinieritas \\
\hline
\end{tabular}

Berdasarkan Tabel 6. Dapat dilihat bahwa data ketahanmalangan dan regulasi diri tidak terjadi multikolinieritas dengan nilai tolerance berturut-turut 0,991, dan nilai VIF berturut-turut 1,009. Uji heterokesdastisitas yang dapat digunakan adalah uji Glejser berbantuan aplikasi program SPSS Versi 21.0

dengan kriteria jika $\rho>0,05$ tidak terjadi heterokedastisidas begitu pula sebaliknya. Berdasarkan hasil uji heterokedastisidas data penelitian pada tabel, dapat dilihat nilai signifikansinya pada variabel ketahanmalangan dan regulasi diri terhadap kompetensi pengetahuan matematika secara berturut-turut adalah 0,901 dan 0,122 >0,05, jadi dapat disimpulkan bahwa tidak terjadi heteroskedastisitas pada model regresi dalam penelitian ini. Hasil uji heterokesdastisitas juga dapat dilihat dari output program SPSS dalam bentuk tabel sebagai berikut.

Tabel 7. Hasil Uji Heteroskesdastisitas Data Siswa

\begin{tabular}{lcc}
\hline \multicolumn{1}{c}{ Variabel } & Sig & Ket \\
\hline Ketahanmalangan & 0,901 & Tidak Terjadi heteroskesdastisitas \\
Regulasi Diri & 0,122 & Tidak Terjadi heteroskesdastisitas \\
\hline
\end{tabular}

Berdasarkan Tabel 7. Dapat dilihat bahwa data ketahanmalangan dan regulasi diri tidak terjadi heteroskesdastisitas dengan nilai sig berturut-turut 0,901 dan 0,122. Uji hipotesis dengan menggunakan teknik analisis regresi linear sederhana dilakukan untuk menguji hipotesis 1 dan 2 dan analisis regresi linear berganda dilakukan untuk menguji hipotesis 3. Adapun hipotesis yang diuji adalah hipotesis nol $\left(\mathrm{H}_{0}\right)$. Hipotesis dalam regresi tersebut diuji dengan menggunakan uji-F dengan kriteria pengujian, terima $\mathrm{H}_{0}$ jika $\mathrm{F}_{\text {reg }}<\mathrm{F}_{\text {tabel, }}$ dan tolak $\mathrm{H}_{0}$ jika $\mathrm{F}_{\text {reg }}>\mathrm{F}_{\text {tabel, }} \mathrm{F}_{\text {tabel }}$ ditentukan dari tabel distribusi $\mathrm{F}$ untuk $\alpha=0,05$. Berdasarkan hasil analisis untuk hasil pengujian hipotesis pertama didapatkan $\mathrm{F}_{\text {reg }}$ didapatkan sebesar 4,366 dan $\mathrm{F}_{\text {tabel }}$ sebesar 3,900, sehingga Ho ditolak, maka dapat disimpulkan bahwa $\mathrm{F}_{\text {reg }}>\mathrm{F}_{\text {tabel, }}$ maka dapat disimpulkan ketahamalangan berpengaruh secara signifikan terhadap kompetensi pengetahuan matematika siswa dengan kontribusi sebesar 36\%. Berikut adalah ringkasannya.

Tabel 8. Analisis Regresi Linier Sed

\begin{tabular}{lcccccc}
\hline \multicolumn{1}{c}{ Sumber } & JK & Db & RK & Fempirik & Fteoritis & Interpretasi \\
\hline Regresi & 161,3936 & 1 & 161,3938 & 4,366 & 3,900 & signifikan \\
Residu & 5840,158 & 158 & 36,96 & & & \\
\hline
\end{tabular}

Hasil analisis untuk hasil pengujian hipotesis kedua $F_{\text {reg }}$ didapatkan sebesar 14,504 dan $F_{\text {tabel }}$ sebesar 3,900, dapat disimpulkan bahwa $F_{\text {reg }}>F_{\text {tabel, }}$ sehingga Ho ditolak, maka regulasi diri berpengaruh signifikan terhadap kompetensi pengetahuan matematika siswa kelas $\mathrm{V}$ dengan kontribusi 25,6\%. Berikut adalah ringkasannya.

Tabel 9. Analisis Regresi Linier Sederhana Regulasi Diri

\begin{tabular}{lcccccc}
\hline \multicolumn{1}{c}{ Sumber } & JK & Db & RK & Fempirik & Fteoritis & Interpretasi \\
\hline Regresi & 491,7107 & 1 & 491,7170 & 7,023 & 3,900 & signifikan \\
Residu & 5356,233 & 158 & 33,90 & & & \\
\hline
\end{tabular}

Hasil analisis untuk hasil pengujian hipotesis ketiga didapatkan $\mathrm{F}_{\text {reg }}$ didapatkan sebesar 27,039

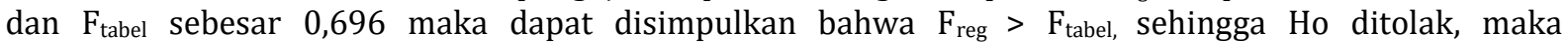
ketahanmalangan dan regulasi diri berpengaruh signifikan terhadap kompetensi pengetahuan matematika siswa kelas V dengan kontribusi yang didapat sebesar 25\%. Berikut adalah ringkasannya. 
Tabel 10. Analisis Regresi Linier Berganda

\begin{tabular}{lcccccc}
\hline \multicolumn{1}{c}{ Sumber } & JK & Db & RK & Fempirik & Fteoritis & Interpretasi \\
\hline Regresi & 1498,2 & 1 & 749,12 & 27,039 & 3,054 & signifikan \\
Residu & 4349,7 & 157 & 27,705 & & & \\
\hline
\end{tabular}

Pada dasarnya pencapaian kompetensi pengetahuan matematika dapat optimal jika proses pembelajaran didalam kelas berlangsung dengan baik. Keberhasilan siswa dalam mempelajari matematika dapat diukur dari cara siswa mengikuti pembelajaran tersebut dan seberapa fokus siswa memahami materi yang ada. Siswa dengan ketahanmalangan yang tinggi tidak akan menyerah dalam menghadapi kesulitan dalam belajar, terutama dalam belajar matematika, serta siswa akan selalu berusaha untuk dapat memecahkan suatu masalah dalam pembelajaran (Nas, 2018). Sejalan dengan teori Alwisol (2006) tentang climbers, yang menyatakan untuk mencapai puncak (keberhasilan) mereka harus berusaha menembus segala rintangan yang menghadang, untuk menghadapi rintangan diperlukan fisik dan pikiran yang sehat serta tekad yang kuat. Faktor yang dominan dalam ketahanmalangan ialah sikap pantang menyerah, sikap itu yang harus di terapkan kepada setiap inidividu agar tetap tegar dan gigih menghadapi tantangan dan penderitaan untuk mencapai tujuan (Nursa \& Rosa, 2016). Siswa dengan ketahamalangan tinggi mampu membatasi setiap masalah atau kesulitan yang dialami agar tidak berpengaruh buruk (Cesarini et al., 2020). Ketahanmalangan merupakan kemampuan seseorang dalam mengatasi suatu kesulitan serta memecahkan masalah dalam kehidupannya (Sofyani \& Susanto, 2019). Pendapat tersebut sejalan dengan pendapat oleh Yudana \& Dantes (2013) yang menyatakan ketahanmalangan memiliki kontribusi yang baik bagi kinerja seseorang. Selain ketahanmalangan yang mendominasi, regulasi diri yang tinggi juga sangat bermanfaat bagi siswa itu sendiri, dengan adanya regulasi diri diharapkan siswa mampu mengatur dan merancangkan waktu belajarnya sendiri (Sagita \& Mahmud, 2019). Regulasi diri tidak akan dapat dikembangkan jika tidak ada dorongan dari dalam lingkungan maupun orang sekitar, maka dari itu perlu ditekankan pada individu bagaimana cara mengatur regulasi diri dalam dirinya sendiri (Anindyta \& Suwarjo, 2014). Begitu juga siswa dengan regulasi diri tinggi dapat mengatasi dan mengontrol dirinya agar tujuan yang akan ia tuju tercapai karena regulasi diri dalam pembelajaran dapat membangkitkan pikiran siswa dan kemampuan siswa untuk mengatur dirinya sendiri (Minauli, 2011). Pernyataan tersebut sependapat juga oleh Zulaikha (2014) yang menyatakan antara AQ terhadap minat belajar terdapat hubungan yang positif dan oleh Rukmana (2016) yang menyatakan antara AQ dengan hasil belajar matematika berpengaruh secara signifikan. Sejalan juga oleh penelitiannya (Noviyanti, 2017) yang menyatakan terdapat hubungan yang signifikan antara regulasi diri dengan hasil belajar fisika siswa. dan oleh (Hastuti, 2019) yang menyatakan bahwa regulasi diri memberikan pengaruh yang signifikan terhadap hasil belajar siswa.

Adapun implikasi yang didapatkan dalam penemuan ini menunjukkan bahwa ketahanmalangan dan regulasi diri dapat memberi pengaruh pada kompetensi pengetahuan matematika siswa sekolah dasar. Dengan demikian penelitian ini membuktikan bahwa semakin tinggi ketahanmalangan, maka semakin tinggi pula regulasi diri siswa. Guru dapat memberikan saran berupa alternatif jawaban dan siswa dapat mengikuti apa yang menjadi pilihannya berdasarkan saran dan jalan keluar dari guru. Dengan demikian, siswa akan menjadi lebih tahan dalam menghadapi kesulitan dalam belajar, terutama dalam belajar matematika, dan ketahanmalangan siswa dapat berkembang dengan baik sehingga nantinya siswa mendapatkan hasil yang maksimal. Sama halnya dengan regulasi diri agar guru menjadikan regulasi diri sebagai model atau patokan untuk meningkatkan cara belajar siswa di dalam kelas dengan menetapkan tujuan pembelajaran mereka, memonitoring cara mereka belajar, mengatur perilaku mereka agar nantinya dapat mencapai tujuan tertentu.

\section{KESIMPULAN}

Banyak ditemui kesulitan dalam pendidikan matematika, diantaranya cara pandang individu yang berbeda-beda. Pada proses belajar mengajar sangat diperlukan sikap siswa yang memiliki ketahanmalangan yang tinggi dimana siswa akan berusaha menemukan jawaban dari setiap permasalahan matematika sehingga ia akan mendapatkan pengetahuan matematika yang sebaik mungkin, jika ketahanmalangan yang dimiliki lemah, individu tersebut akan cepat menyerah dalam menghadapi permasalahan matematika dan cenderung malas untuk mengerjakannya karena merasa tidak memiliki kemampuan untuk menyelesaikannya. Selain ketahanmalangan, regulasi diri perlu dimiliki untuk dapat menempatkan diri untuk mencapai target. Berdasarkan hasil analisis data serta pembahasan maka dapat disimpulkan bahwa terdapat pengaruh signifikan ketahanmalangan dan regulasi diri terhadap 
kompetensi pengetahuan matematika siswa kelas V SD. Sesuai temuan penelitian yang diperoleh, maka saran yang dapat diberikan kepada guru dan peneliti lainnya agar menggunakannya sebagai referensi dalam mengembangkan penelitian lainnya serta menggunakannya sebagai pendukung sarana sumber belajar sehingga nantinya dapat meningkatkan kualitas pendidikan dengan cara mengoptimalkan pencapaian tujuan belajar siswa dengan mengembangkan ketahanmalangan dan regulasi diri siswa agar lebih meningkat dimana nantinya ketahanmalangan dan regulasi diri ini bisa meningkatkan kompetensi pengetahuan matematika siswa. Hasil penelitian ini dapat digunakan sebagai pertimbangan untuk melanjutkan penelitian-penelitian yang sumbernya dapat diperoleh pada penelitian ini.

\section{DAFTAR PUSTAKA}

alwisol. (2006). Psikologi Kepribadian Edisi Revisi (Pp. 58-59). Umm Press.

Amelia, I. (2018). Model-Model Pembelajaran Matematika. Pt. Bumi Aksara.

Anindyta, P., \& Suwarjo, S. (2014). Pengaruh Problem Based Learning Terhadap Keterampilan Berpikir Kritis Dan Regulasi Diri Siswa Kelas V. Jurnal Prima Edukasia, 2(2), 209. Https://Doi.Org/10.21831/Jpe.V2i2.2720

Anisa, A., Kodirun, K., Busnawir, B., \& Rahmat, R. (2019). Pengaruh Pengetahuan Dasar Matematika Terhadap Hasil Belajar Matematika Siswa Kelas X Sma Negeri 1 Lawa. Jurnal Pendidikan Matematika, 10(1), 100. Https://Doi.Org/10.36709/Jpm.V10i1.5648

Artyanti, R., \& Rustika, I. M. (2016). Hubungan Antara Self Regulated Learning Dan Kelekatan Remaja Awal Terhadap Ibu Dengan Prestasi Belajar Siswa Smp N 6 Denpasar. Jurnal Psikologi Udayana, 3(1), 54-63. Https://Doi.Org/10.24843/Jpu.2016.V03.I01.P06

Ayulina, Ngurah, G., \& Agustika, S. (2020). Kontribusi Konsep Diri Dan Motivasi Belajar Terhadap $\begin{array}{llll}\text { Kompetensi } & \text { Pengetahuan } & \text { Matematika. }\end{array}$ Https://Ejournal.Undiksha.Ac.Id/Index.Php/Jjpgsd/Article/View/24580

Cesarini, D. A., Yusuf, M., \& A., L. S. S. (2020). Hubungan Antara Adversity Quotient Dan Motivasi Berprestasi Dengan Kecemasan Berbahasa Asing Pada Mahasiswa Tingkat Akhir Program Sarjana $\begin{array}{lllll}\text { Uns. Seurune, Jurnal } & \text { Psikologi }\end{array}$ Http://Jurnal.Unsyiah.Ac.Id/Seurune/Article/View/15631

Dewi, M., \& Suhendri, H. (2017). Pengaruh Kemandirian Dan Ketahan Malangan (Adversity Quotient) Terhadap Kemampuan Pemecahan Masalah Matematika. Jurnal Intraksi, 2(3), 724-735. Https://Journal.Lppmunindra.Ac.Id/Index.Php/Repository/Article/View/2042

Fadhilah, N. T. R. (2020). Hubungan Antara Daya Ketahanmalangan Dan Minat Belajar Dengan Kompetensi Pengetahuan Matematika Siswa. Eduhumaniora / Jurnal Pendidikan Dasar Kampus Cibiru, 12(1), 37-47. Https://Doi.Org/10.17509/Eh.V12i1.17687

Ghufron, M. N. (2017). Teori-Teori Psikologi (Pp. 77-79). Ar-Ruzz Media.

Hamdi, S., Suganda, I. A., \& Hayati, N. (2018). Developing Higher-Order Thinking Skill (Hots) Test Instrument Using Lombok Local Cultures As Contexts For Junior Secondary School Mathematics. $\begin{array}{llll}\text { Research And Evaluation In } & \text { 126-135. }\end{array}$ Https://Doi.Org/10.21831/Reid.V4i2.22089

Handayani, R., \& Abadi, I. B. G. S. (2020). Pengaruh Model Pembelajaran Langsung Berbantuan Media Gambar Terhadap Kompetensi Pengetahuan Matematika Siswa Kelas Iv Sd. 25(1), 120-131. Https://Ejournal.Undiksha.Ac.Id/Index.Php/Mi/Article/View/24767 
Hastuti, R., \& Rahman, U. (2019). Pengaruh Regulasi Diri ( Self Regulation ) Dan Motivasi Belajar Terhadap Hasil Belajar Biologi Pada Peserta Didik Kelas Xi Mia Man Bulukumba. Jurnal Al-Ahya, 1(2), 42-52. Http://Journal.Uin-Alauddin.Ac.Id/Index.Php/Alahya/Article/View/8074

Hibatul, A. (2019). Hubungan Antara Ketahanmalangan Dengan Orientasi Bidang Pekerjaan. 7(4), 910920. Ournal.Psikologi.Fisip-Unmul.Ac.Id/Site/Wp-Content/Uploads/2019/10/Ejournal Tahfizh Hibatul Aufar (10-09-19-11-11-46).Pdf

Kusaeri, K., \& Mulhamah, U. N. (2016). Kemampuan Regulasi Diri Siswa Dan Dampaknya Terhadap Prestasi Belajar Matematika. Jurnal Review Pembelajaran Matematika, 1(1), 31-42. Https://Doi.Org/10.15642/Jrpm.2016.1.1.31-42

Minauli, I. (2011). Hubungan Antara Efikasi Diri Dan Regulasi Diri Dalam Belajar Dengan Prestasi Akademik Mahasiswa. In Analitika (Vol. 3, Issue 2, Pp. 79-84). Https://Ojs.Uma.Ac.Id/Index.Php/Analitika/Article/View/748

Nas, S. (2018). Pengaruh Adversity Quotient, Motivasi Belajar, Dan Persepsi Siswa Tentang Cara Mengajar Guru Terhadap Hasil Belajar Matematika Siswa Kelas Ix Smpn Se-Kecamatan Wara Utara. 3, 113124. Https://Journal.Uncp.Ac.Id/Index.Php/Pedagogy/Article/View/1191

Noviyanti, S., Simatupang, B., Islami, N., \& Nasir, M. (2017). Correlation Of Learning Motivation And SelfRegulated Learning With Physisc Learning Result Of Class Xi Sma Negeri 4 Pekanbaru Lesson Year 2016 / 2017 Learning Dengan Hasil Belajar Fisika Siswa Kelas Xi. 2017(2), 1-13.

Nur, F., \& Latief, A. K. (2016). Pengaruh Self-Esteem Dan Self-Regulation Terhadap Hasil Belajar Matematika Siswa. Jurnal Biotek, 4(36), 244-261. Http://Journal.UinAlauddin.Ac.Id/Index.Php/Biotek/Article/View/1796

Nursa'adah, F. P., \& Rosa, N. M. (2016). Analisis Kemampuan Berpikir Kreatif Kimia Ditinjau Dari Adversity Quotient, Sikap Ilmiah Dan Minat Belajar. Formatif: Jurnal Ilmiah Pendidikan Mipa, 6(3), 197-206. Https://Doi.Org/10.30998/Formatif.V6i3.992

Paul. G. Stoltz. (2007). Adversity Quotient. Mengubah Hambatan Menjadi Peluang (Pp. 18-20). Grasindo.

Putry, N. D., Armen, \& Putri, D. H. (2017). Hubungan Kemampuan Self-Regulated Learning Dengan Hasil Belajar Ipa Siswa Smpn 3 Padang. Berkala Ilmiah Bidang Biologi, 1(2), 210-217.

Retnawati, H., Djidu, H., Kartianom, Apino, E., \& Anazifa, R. D. (2018). Teachers' Knowledge About HigherOrder Thinking Skills And Its Learning Strategy. Problems Of Education In The 21st Century, 76(2), 215-230.

Rukmana, I., Hasbi, M., \& Paloloang, B. (2016). Hubungan Adversity Quotient Dengan Hasil Belajar Matematika Siswa Kelas Xi Sma Negeri Model Terpadu Madani Palu. Jurnal Elektronik Pendidikan Matematika Tadulako, 3(3), 325-333. Http://Jurnal.Untad.Ac.Id/Jurnal/Index.Php/Jepmt/Article/View/7220

Sagita, N. N., \& Mahmud, A. (2019). Peran Self Regulated Learning Dalam Hubungan Motivasi Belajar, Prokrastinasi Dan Kecurangan Akademik. Economic Education Analysis Journal, 8(2), 516-532. Https://Doi.Org/10.15294/Eeaj.V8i2.31482

Setiawan, S. (2017). Pengaruh Bentuk Pola Asuh Orang Tua Dan Regulasi Diri Terhadap Disiplin Siswa (Smp 17 Agustus 1945 Samarinda). Ejournal.Psikologi. Isip-Unmul.Ac.Id, 5(2), 310-319.

Sofyani, N., \& Susanto, R. (2019). Analisis Keterkaitan Kecerdasan Emosional (Emotional Quotient ) Dan Ketahanmalangan (Adversity Quotient) Dalam Pembentukan Motivasi Belajar Siswa Kelas Va Di Sekolah Dasar Negeri Jelambar Baru 01. Dinamika Sekolah Dasar, 4, 1-13. Https://Journal.Pgsdfipunj.Com/Index.Php/Wahana/Article/View/96 
Suhendri, H., \& Ningsih, R. (2018). Peranan Ketahanmalangan Dan Kreativitas Dalam Pembelajaran Matematika. Jurnal Penelitian Dan Pembelajaran Matematika, 11(1). Https://Doi.Org/10.30870/Jppm.V11i1.2982

Sukardi. (2012). Metodologi Penelitian Pendidikan (Pp. 136-137). Pt. Bumi Aksara.

Umam, K., Nusantara, T., Parta, I. N., \& Hidayanto, E. (2018). Mathematical Meaning In Modelling Context Through The Onto-Semiotics Approach Http://Journal2.Um.Ac.Id/Index.Php/Ijoimt/Article/View/3368

Widnyana Karya, N. T. J. (2017). Pengaruh Pendekatan Inkuiri Berbantuan Assesmen Autentik Terhadap Ketahanmalangan Dan Hasil Belajar Matematika. Penerapan, 6(2).

Yudana, M., \& Dr. Gede Rasben Dantes, S. (2013). Kontribusi Motivasi Berprestasi, Disiplin Kerja, Dan Ketahanmalangan (Adversity Quotient) Terhadap Kinerja Profesional Guru Sma Negeri Di Kecamatan Karangasem Kabupaten Karangasem Bali. Jurnal Administrasi Pendidikan, 4(1), 1-13. Https://Doi.Org/10.23887/Japi.V4i1.1011

Zulaikha, S., Pendidikan, J., Sekolah, G., \& Ganesha, U. P. (2014). Hubungan Antara Adversity Quotient ( Aq ) Dan Minat Belajar Dengan Prestasibelajar Di Kelurahan Pedungan Jurusan Pendidikan Guru Sekolah Dasar , Fip Universitas Pendidikan Ganesha. 2. Https://Ejournal.Undiksha.Ac.Id/Index.Php/Jjpgsd/Article/View/3026 